\title{
LITERARY HISTORY CONCEPTIONS OF B. LEPKY
}

\author{
STEPAN KHOROB
}

\begin{abstract}
The article addresses the issue of the methodological conceptualism developed by Ukrainian literary historian Bohdan Lepky. The analysis proves that his textbook Nacherk istorii ukrainskoi literatury (An Essay on the History of Ukrainian Literature) retains its literary value and its place among the textbooks and study guides published in the first half of the 20th century.
\end{abstract}

Keywords: B. Lepky, national writings, methodology, conceptions, history of Ukrainian literature.

It appears that until recently, only literary critics have been able to discuss the activity of Bohdan Lepky as a historian of Ukrainian national literature. And it does not look as if it had been their main scientific interest (see the literary critical essays of Zenon Kuzela, Vasyl Simovych, Mykola Ilnytskyi, Roman Hromiak, Volodymyr Kachkan; and the general critical reviews of Mykola Yevshan, Bohdan Romanenchuk, Marian Kozak, Mykhailo Naienko, Oleksa Myshanych). The scholars who studied Bohdan Lepky's literary-historical legacy often made references to the works of Ivan Franko, Dmytro Chyzhevsky, Mykhailo Vozniak, Yevhen Pelenskyi; the latter discussed, in one way or another, the factor of methodological conceptualism in the history of Ukrainian literature.

Yet the methodological conceptions of Bohdan Lepky as a historian of Ukrainian literature have not been studied comprehensively. Now, in the light of researches carried out by national literary critics and diaspora scholars (Serhiy Yefremov, Mykola Zerov, Pavlo Fylypovych, Dmytro Chyzhevsky, Leonid Biletsky, Mykola Hnatyshak, Yevhen Pelenskyi, Marian Jakóbiec), the importance of this aspect of Bohdan Lepky's activity has become evident; it is clear that the study of his methodological instruments requires a new approach. Recent publications of theoretical, methodological, literaryhistorical materials and articles on the issue emphasize the significance of Lepky's ideas.

Bohdan Lepky published his two-volume Nacherk istorii ukrainskoi literatury (An Essay on the History of Ukrainian Literature) in Kolomyia in 1909-1912; its purpose was clearly defined: it was 'a textbook for general use'. But he started his work as a literary historian earlier, when he was working as a high school / Gymnasium teacher of Ukrainian philology, literature in particular, in Berezhany (1895) and Kraków (1899-1914). The years spent in Kraków, where Lepky was teaching at Jan III Sobieski High School and at the Gymnasium of St. Hyacinth, were marked by his first achievements. According to Polish researcher Marian Jakóbiec, it was in Kraków, the cultural centre of Western Galicia, that in 1910, 'Lepky passed the teacher's examination in the Polish and the Ukrainian languages as his major subjects and in the Latin language as a subsidiary subject; on September 1, 1911, he was employed as an "authorized teacher" at the Third Gymnasium in Kraków. At the same time, he was teaching the 
Ukrainian language and Ukrainian literature at the Jagiellonian University (1899-1914) and the Male Teachers' Seminary (1908-1914)'* [1, p. 529].

Another important fact of Bohdan Lepky's biography should be mentioned here: in 1899, he translated Slovo o polku Ihorevim (The Tale of Igor's Campaign) into the Polish language and made analysis of its aesthetic features; the work significantly affected his research intentions. In the commentaries to his Pysannia. T. 3 (Writings. Vol. 3) (Kyiv - Leipzig, 1922), the author said, 'it took me a month to do the translation, but I dedicated almost a year to a research on this greatest work of our literature of the preTatar period' [2, vol.1, p. 789]. According to Oleksa Myshanych, 'being triggered by the translation of The Tale, the study of the epic poem developed into a large chapter in the first volume of An Essay on the History of Ukrainian Literature (Chapter 6, p. 256-299), which can be regarded as a separate monograph on The Tale. In it, all aspects of the research on The Tale are thoroughly discussed: its historical basis, plot, literary elements, main idea, mythology, the factor of folk poetry (especially the dumas ${ }^{+* *}$ ), the issue of its authorship, the history of this national epic, its imperishability and meaning, the major bibliography. In fact, Bohdan Lepky summarized the almost one-hundred-year-long history of research studies on The Tale, from W. Hanka, M. Gramatin and M. Maksymovych to his contemporaries, P. Vladimirov, V. Kaldash, V. Kotsovsky and I. Franko' [3, p. 43-44].

Thus it can be maintained that Buhdan Lepky started his activity as a literary historian at the educational establishments of Berezhany and Kraków, where he was teaching the Ukrainian and Polish languages, translating The Tale and carrying out his research on the poem.

Lepky honed his historical methodological conceptions in a series of publications about Ukrainian authors, in the process of editing their works and writing introductions to them. For example, he appears to be the first scholar to analyze Vasyl Stefanyk's novellas (Lviv, 1903); his essay on the poetic and folkloristic activities of Markiyan Shashkevych (Kolomyia, 1912) is a valuable piece of literary criticism. During World War I, he kept working in the field of literary-historical criticism. At first he lived in Vienna and then, in the Austrian towns of Wetzlar am Lahn and Salzwedel (till 1919), where he taught Ukrainians kept in the prisoners of war camps. In 1915, a collective monograph on the history of Ukrainian literature was published in Vienna, and Bohdan Lepky and Vasyl Simovych contributed to the publication. The second, completed edition of the book was published in Wetzlar am Lahn in 1918.

After the war, Lepky moved to Germany; the Berlin University offered him the position of Docent at the Department of Eastern Languages (Seminar für Orientalische Sprachen), which he, being actively engaged in publishing and scholarly work, declined. Lepky proved to possess remarkable methodological skills, and in Berlin his talent of a literary critic and a literary historian developed to the full. 'At that time, he prepared a three- and a five-volume editions of the works of T. Shevchenko, Marko Vovchok, H. Kvitka-Osnovianenko, P. Kulish, I. Kotliarevsky, O. Storozhenko, S. Rudansky, I. Tobilevych, Yu. Fedkovych and others' [1, p. 531]. Together with Sevchenko's works, Lepky published the extensive literary-historical paper Pro zhyttia i tvory Tarasa Shevchenka (About the Life and Works of Taras Shevchenko) (1919). He also wrote introductions, afterwords and commentaries to the other editions; quite often those pieces were real methodological discoveries.

At the end of 1925, Bohdan Lepky left Berlin and returned to Kraków, where he taught philology at St. Anna's Gymnasium and then at Hoene-Wronski Gymnasium; at the same time, as a Research and Teaching Assistant, he gave lectures on the history of Ukrainian literature at the Jagiellonian University; on January 1, 1935, the University awarded Lepky the title of Extraordinary Professor. He taught a special course on Polish-Ukrainian literary relations and published the reference textbook Narys ukrainskoi literatury (An Essay on Ukrainian Literature) in Polish (the series Sloviany (Slavs), Warsaw - Kraków, 1930). The textbook discussed the issues of Ukraine, her people, the language and the most important literary works of Old Rus'; though, only a small section of the book was dedicated to literature. Bohdan Lepky's book Try portrety. Franko - Stefanyk - Orkan (Three Portraits. Franko - Stefanyk

\footnotetext{
${ }^{*}$ This and all other quotations are translated from the sources listed in References.

** Duma - a Ukrainian folk ballad.
} 
- Orkan) (Lviv, 1937) was another interesting literary-historical study; the analysis the works of the three - two Ukrainian and one Polish - authors was based on the principles of comparativism.

Still, it is believed that the most valuable work of Lepky as a critic and literary historian is his twovolume Nacherk istorii ukrainskoi literatury (An Essay on the History of Ukrainian Literature) published in the early $20^{\text {th }}$ century ${ }^{*}$. At the beginning of the book, the author clearly explicated his methodological conception, a "fundamental principle" of the selection and analysis of literary works is beauty, i.e. the emergence of purely aesthetic feelings in Ukrainian verbal art ("oral and written")' [4, p. 21-23]. In fact, Bohdan Lepky's textbook (it ended with the analysis of the late $17^{\text {th }}$-century works) discussed the folklore and mythological principles of Ukrainian writings, the phenomena and principles of old Ukrainian literature as an inherent part of our general national culture. In other words, following his own literary history conception, Bohdan Lepky selected only 'beautiful' (the best) pieces of national literature for his textbook. According to Mykhailo Naienko, 'it was a kind of antipode to Ivan Franko's Narys istorii ukrainsko-ruskoi literatury do 1890 roku (An Essay on the History of Ukrainian-Rus' Literature Before 1890) that was published in Lviv in 1910; in Franko's work, the material was basically organized according to a bibliographical framework' [5, p. 735-736].

In his review of Bohdan Lepky's textbook, Mykola Yevshan wrote, 'I would like to say a few words about a new way chosen by the author rather than about the textbook itself, about the new values, which he saw in Old Rus' writings; I would also like to discuss to what degree the author succeeded in using this new method. It is obvious that the author's new way, which he tried to show to a reader, was different from the one suggested by the late Ohonovsky in his history of literature; it appears that, first of all, the author wanted to touch a poetic string of the heart, a string that would make his reader reflect on the old writings, would let them feel their spirit. "They (i.e. Old Rus' writings) should be read and contemplated about, one should try to get the perspective of the old times." The author believed that imagination and intuition could help a reader to perceive that perspective of the old times in the chronicles, which might seem dry at first glance, and in other literary monuments Old Rus'. Of course, one had to feel the pulse of life of Ancient Rus', to breathe life into those chronicles in order to make them vibrate with the echo of the past. And the author was up to the task. He tried to grasp "that poetry of life inherent in pagan rituals, songs, tales, festival activities." The author proved to be a comprehensive analyst of the whole epoch rather than a bibliographer; being inclined to a broader approach, he tried to paint with broad brush strokes, to adopt a broad style and to convey the spirit of the time through several features' [6, p. 528].

The first volume of Lepky's Essay was dedicated to the historical development of Ukrainian national literature 'before the Tatar invasion', i.e. before The Tale of Igor's Campaign (six chapters). The author planned the second volume to cover the period 'from the Tatar invasion to Kotliarevsky'. The plan was only partially implemented. According to Oleksa Myshanych, as a literary historian, Lepky the 'made use of a philological method, paying attention to the artistic aspect of works, their ideological and aesthetic content, and the system of imagery and style' [3, p. 47]. Before him, Mykola Yevshan said, 'If he had written a twenty-page-long essay on Old Rus' writings, it would have been a truly original literary piece, Lepky's poetic deed. But the author consciously narrows his horizons, limits his deep poetic inclinations, abandons his aesthetical methodology. In the introduction, the author does speak of "the task to investigate how an aesthetic feeling started to emerge in our works of literature, how sensitivity and imagination were developing in them; the task to make beauty, to which human spirit aspires, which we can find in the wonderful songs of our people, a fundamental principle of literature"; but then he says that the method is inapplicable. The author starts writing the history of literature, but he has not decided what principle of analysis to use; as a result, we see a mechanical combination of two methods, the mixture of poetics and dry bibliographic material' [6, p. 529].

It is obvious that Bohdan Lepky's literary history conception was influenced by the aesthetics of the literary group Moloda Muza (The Young Muse); Lepky shared its ideals and tried to introduce its

\footnotetext{
${ }^{*}$ The first edition of the textbook was published by Yakiv Orenstein in Kolomyia (1909-1912); the second, completed, Kyiv - Leipzig edition appeared in 1923.
} 
philological methodology into the literary criticism of the early $20^{\text {th }}$ century. According to the methodology of The Young Muse, artistically perfect literary works, folklore and mythologic pieces are, on the one hand, the object of analysis; on the other, these 'aesthetically beautiful' phenomena are landmarks in the development of the national spirit.

Later, Bohdan Lepky made significant corrections to the proposed literary conception (see the above citations). Working on his Essay on the History of Ukrainian Literature, he realized that such an approach might affect the very idea of the continuity of the literary-historical process with its undeniable achievements ('beautiful' pieces) and mediocre ('imperfect') phenomena. Had the only criterion been the aesthetic beauty of a piece (a feature of The Tale of Igor's Campaign, folklore and mythologic tales and folk poetry), a vast corpus of chronicles and polemic literature, whose worth lies in their historic content rather than in aesthetic perfection ('artistic beauty'), would have been left out in the cold.

Thus in his Essay, Bohdan Lepky had to rely on the methodological principles of the historical school developed by Ivan Franko, Ivan Vahylevych, Serhiy Yefremov and others. It is only in some cases that the author focused on specific artistic 'devices and figures'; for example, analyzing the text of The Tale, this 'immortal poem', he made a subtle distinction between the real historic events and the 'fictitious world', aesthetically substantiated their unity from the perspectives of content and form, and emphasized the indivisibility of the literary and folklore traditions.

Bohdan Lepky pointed out 'the poem's connection with the imagery of folk ballads; the latter perfectly agrees with a purely literary style, "poetic symbols, figures and tropes, all the features of a fully developed artistic literary form"' [7, p. 188]. Presumably, artistic value, which for Bohdan Lepky was the key factor in aesthetic beauty, would have become a conceptual principle of his Essay's methodology, had he written about Ukrainian baroque poetry, the Renaissance pieces or the works of particular Ukrainian authors, beginning from the $18^{\text {th }}$ century, such as Hryhorii Skovoroda, Ivan Kotliarevsky and others.

Later, in the 1930s, Bohdan Lepky discussed these phenomena of Ukrainian national literature in the relevant sections of his Essay on Ukrainian Literature (Warsaw - Kraków). But it was not an attempt at aesthetical analysis focused on the artistic characteristics of the works. It was done for educational purpose, and we can presume that this Essay was based on Lepky's introductory lecture courses for the students of the Jagiellonian University in 1925-1932. He paid more attention to the study of Ukrainian folklore, rites and rituals (for example, those performed at weddings, Christmas and Easter rituals and others). The researcher considered them to be 'highly artistic'; he admired their elaborate aesthetic forms, especially those of songs. In An Essay on the History of Ukrainian Literature, relying on his methodological conception of the 'beauty of aesthetic feelings', Lepky did a careful artistic analysis of this aspect of Ukrainian poetic folklore [4, p. 22].

Thus in a number of articles written in different times and in his textbook on the history of Ukrainian literature, Bohdan Lepky used the methodological principles that, on the one hand, relied (to an extent) on the approach developed by The Young Muse, whose members were the proponents of the philological school in Ukrainian literary criticism ('literary phenomenon as the manifestation of the specificity of national verbal art'), and on the other, concentrated on certain aesthetically perfect works, 'only those that are beautiful', literary pieces of unsurpassed excellence and national importance. In his speeches, numerous reviews and research studies, Lepky emphasized that his methodological conceptualism mostly followed from his 'own scientific and artistic activity', his 'own experience in perceiving Ukrainian national literature' that 'is remembered, first of all, due to its original artistic masterpieces' [8, p. LXX-LXXI].

Bohdan Lepky believed (as he often stated in his critical and epic works) the national element to be the 'principium' of literature in general. Evidently, it followed from his idea of 'artistic creativity' as a natural manifestation of the national ethos with its language, character, traditions and rites, even the national psyche. The scholars, who research Bohdan Lepky's activity, his literary history works in particular, indicate that in his Essay, he 'consciously drew attention to national patriotic texts that promoted the idea of the unity of Rus', the principles of democracy and altruism. He stressed that the 
weaknesses of old Ukrainian literature resulted from the lack of quality education, the absence of a common literary language, the difference between the bookish and living colloquial language' [9, p. 47].

Let us turn to the literary theory of Oleksandr Potebnia: being an element of thinking and expression of a particular nation, language affects the formation of the general principles of literary (text) analysis. Judging by Bohdan Lepky's later essays on the works of Ivan Kotliarevsky, Taras Shevchenko, Panko Kulish, Leonid Hlibov, Oleksa Storozhenko, Marko Vovchok, Yuriy Fedkovych, Ivan Franko, Vasyl Stefanyk and other authors, the national element was obviously one of the major principles of the critic's methodological conceptualism.

Bohdan Lepky's methodological conception was further developed by Ukranian literary historians Leonid Biletsky (Istoriia ukrainskoi literatury. Narodna poeziia (A History of Ukrainian Literature. Folk Poetry), 1937, 1947) and Mykola Hnatyshak (Istoriia ukrainskoi literatury (A History of Ukrainian Literature), 1941). "Having discussed the notion of "literature", the specificity of its imagery, its aesthetic functionality, its being part of the general history of the nation, its natural connection with folklore, preChristian faith and mythology in the introduction (to his History. - S. Kh.),' Leonid Biletsky 'comes up with two important ideas: he suggests a periodization of epochs marked by cultural achievements of the Ukrainian nation and points out outstanding aesthetic phenomena created [...] by this nation throughout its centuries-long history' [9, p. 375]. In his turn, Mykola Hnatyshak stated in his History of Ukrainian Literature that 'a truly objective psychological, cultural-historical and aesthetical analysis of literary works leads to the conclusion that even in the domain of poetic beauty, even in the aesthetic sense, the role of ideological, ethical and social principia is no less important than that of aesthetical ones'; therefore we should 'carefully combine the aesthetical assessment of a literary work with the ideological, ethical, national and social ones' [10, p. 17-18].

It is evident that every Ukrainian literary historian had his own approach to the analysis of the national literature, its periodization and development, and his own instruments of analysis. Bohdan Lepky moved from the beginnings of the literary and folklore traditions to the greatest, 'aesthetically beautiful' works of Ukrainian national literature, the ones that arouse aesthetic feelings. It was, in a way, the rejection of a bibliographical principle used by Ivan Franko in his An Essay on the History of Ukrainian-Rus' Literature Before 1890.

Serhiy Yefremov's Istoriia ukrainskoho pysmenstva (A History of Ukrainian Literature), published in the same period as Bohdan Lepky's work, was based on a radically different methodological approach: he believed the history of literature to be not just the 'analysis a literary work', but the history of ideas in a broad sense of the word, involving the stages in the development of the state's autonomy, the periods of national dependence, the national revival, etc. According to Mykola Zerov, such an approach involuntarily resulted in ignoring the works of Ukrainian literature beyond the category of 'the national liberation idea'. Yet the neo-classic believed that on the whole, Serhiy Yefremov's methodological principle promoted the 'canon of Ukrainian literature'.

Like Bohdan Lepky in An Essay on the History of Ukrainian Literature, Leonid Biletsky in his History of Ukrainian Literature. Folk Poetry emphasized 'the description of the national type' in oral and written literature; and like Serhiy Yefremov, Biletsky suggested its periodization - the pre-Christian, Christian, historical periods. Later, Mykola Hnatyshak and Dmytro Chyzhevsky, like their forerunners, deviated from the usual 'canon of Ukrainian literature'; at the same time, their methodological conceptions involved preserving the 'principium of the national' in the selection and analysis of literary-historical materials. Each of them in his time began constructing the history of Ukrainian literature 'according to the principle of the change of literary styles, not the change of social epochs, economic systems or national liberation movements' [11, p. 669]. They regarded literature in general and Ukrainian literature in particular as the art of the word, the criteria of its analysis being high artistic and imagery value (regardless of its attribute - 'beautiful', 'perfect', 'aesthetic', 'socially aesthetic' or even 'nationally minded'). Definitely, Bohdan Lepky's methodological conceptualism was a contribution to Ukrainian literary history criticism.

Unfortunately, Bohdan Lepky's two-volume Essay on the History of Ukrainian Literature, designed as a textbook for high schools and a self-study guide to Ukrainian literature, remains underestimated. The 
third volume was never published. Neither during the author's lifetime nor after his death, literary critics paid due attention to An Essay. Lepky realized that he was writing his history of national literature (a work, which he did not manage to complete) in 'a foreign country, far away from our research centres, even from the printing house, in which (it) was issued; moreover, the circumstances were not especially favourable to the author' [4, p. 306-307]. At the same time, he believed that 'it is literary works, not textbooks that teach us literature' [4, p. 307]; so Bohdan Lepky considered his Essay to be 'only an encouragement, and sometimes a guide to the world of our writings of the pre-Tatar period' [4, p. 308]. It should be mentioned that in his time, there was only one such 'guide' for Galician secondary-school 'young folks', Istoriia literatury ruskoi (A History of Rus' Literature) by Omelian Ohonovsky. It was far from being enough; there was a need for a textbook that would rely on innovative approaches to literature, both old and modern. So Bohdan Lepky's work on the history of national literature was really important. His Essay contained diverse, comprehensible educational material; the author's attitude was unbiased, and he paid close attention to the original literary works.

Hopefully, we will see a new edition of Bohdan Lepky's Essay on the History of Ukrainian Literature published in Ukraine (like the one published by the late Oleksa Horbach in Munich in 1991), because the author's methodological conceptualism has its own scientific and practical value, and its place in the history of Ukrainian literary criticism.

\section{REFERENCES}

[1] Якубець М. Богдан Яепкий. В: Українознавчі працุі. Талком, Київ, 2017, 529-532. [Iakubets M. Bohdan Lepkyi. In: Ukrainoznavchi pratsi. Talkom, Kyiv, 2017, 529-532.]

[2] Лепкий Б. Твори в двох томах, Т. 1. Наукова думка, Київ, 1997. [Lepkyi B. Tvory v dvokh tomakh, T. 1. Naukova dumka, Kyiv, 1997.]

[3] Мишанич О. Давне українське письменство в науковій та художній спадщині Богдана Депкого. В: Високе небо Богдана Лепкого. Спроба антології у публіцистиці, поезії, пісні. Джура, Тернопіль, 2001, 41-50.

[Myshanych O. Davnie ukrainske pysmenstvo v naukovii ta khudozhnii spadshchyni Bohdana Lepkoho. In: Vysoke nebo Bohdana Lepkoho. Sproba antolohii u publitsystytsi, poezii, pisni. Dzhura, Ternopil, 2001, 41-50.]

[4] Лепкий Б. Начерк історії української літератури, Кн. 1: (До нападів татар). Гадицька Накладня, Коломия, 1909.

[Lepkyj B. Nacherk istoriyi ukrayinskoyi literatury, Kn. 1: (Do napadiv tatar). Galyczka Nakladnya, Kolomyya, 1909.]

[5] Літературознавство і критика: 1917-1940. В: Дончик В.Г. (Ред.) Історія украйнської літератури ХХ століття. Книга перша. Аибідь, Київ, 1993, 731-769.

[Literaturoznavstvo i krytyka: 1917-1940. In: Donchyk V.H. (Ed.) Istoriia ukrainskoi literatury XX stolittia. Knyha persha. Lybid, Kyiv, 1993, 731-769.]

[6] Богдан Лепкий. Начерк історії української літератури. В: Євшан М. Критика. Аітературознавство. Естетика. Основи, Київ, 1998, 528-530.

[Bohdan Lepkyi. Nacherk istorii ukrainskoi literatury. In: Ievshan M. Krytyka. Literaturoznavstvo. Estetyka. Osnovy, Kyiv, 1998, 528-530.]

[7] Наєнко М.К. Історія украӥнського літературознавства і критики. Академія, Київ, 2010.

[Naienko M.K. Istoriia ukrainskoho literaturoznavstva i krytyky. Akademiia, Kyiv, 2010.]

[8] Верниволя В. (Сімович В.) Богдан Лепкий. В: Лепкий Б. Писання. Том I. Вірші. Українська накладня, Київ-Ляйпціг, 1922.

[Vernyvolia V. (Simovych V.) Bohdan Lepkyi. In: Lepkyi B. Pysannia. Tom I. Virshi. Ukrainska nakladnia, Kyiv-Liaiptsig, 1922.] 
[9] Хороб С. Леонід Білецький - історик української літератури. В: Білецький Л. Історія украӥнської літератури. У 2 томах. Том 1. Місто НВ, Івано-Франківськ, 2015, 364-379.

[Khorob S. Leonid Biletskyi - istoryk ukrainskoi literatury. In: Biletskyi L. Istoriia ukrainskoi literatury. U 2 tomakh. Tom 1. Misto NV, Ivano-Frankivsk, 2015, 364-379.]

[10] Гнатишак М. Історія української літератури. Видавництво Юрія Тищенка, Прага, 1941.

[Hnatyshak M. Istoriia ukrainskoi literatury. Vydavnytstvo Yuriia Tyshchenka, Praha, 1941.]

[11] Ільницький М. Ідейно-етичний естетизм (Микола Гнатишак). В: Ільницький М. На перехрестях віку. У 3 книгах. Книга 3. Києво-Могидянська академія, Київ, 2009, 666-668.

[Ilnytskyi M. Ideino-etychnyi estetyzm (Mykola Hnatyshak). In: Ilnytskyi M. Na perekhrestiakh viku. U 3 knyhakh. Knyha 3. Kyievo-Mohylianska akademiia, Kyiv, 2009, 666-668.]

Address: Stepan Khorob, Vasyl Stefanyk Precarpathian National University, 57, Shevchenko Str., IvanoFrankivsk, 76025, Ukraine.

E-mail: kaf.lit@ukr.net

Received: 12.06.2018; revised: 09.11.2018.

Хороб Степан. Історико-літературні концепції Б. Аепкого. Журнал Прикарпатського університету імені Василя Стефаника, 6 (2) (2019), 92-98.

У статті зроблено спробу дослідити методологічний концептуалізм Богдана Лепкого як історика української літератури. Доведено, що “Начерк історії української літератури”, який він видав на початку XX століття як підручник, зберігае свою літературну цінність серед іншого типу підручників і посібників, виданих впродовж першої половини XX століття.

Ключові слова: Б. Лепкий, національне письменство, методологія, концепти, історія української літератури. 